\title{
Analysis of the Initial Stages of Electrocrystallization of Fe, Co and Fe-Co Alloys in Chloride Solutions
}

\author{
Fábio R. Bento and Lucia H. Mascaro* \\ Departamento de Química, Universidade Federal do Paraná, Centro Politécnico s/n, CP 19081, 81531-970 \\ Curitiba - PR, Brazil
}

\begin{abstract}
A eletrodeposição de Fe, Co e ligas de Fe-Co foi investigada a partir de soluções de cloreto em pH 2.0. As ligas Fe-Co foram depositadas a partir de soluções com razão molar de 1:10, 1:1 e 10:1. O processo de eletrocristalização dos metais foi estudado através de saltos potenciostáticos. O modelo de Scharifker e Hills foi utilizado para analisar os transientes de corrente. Os resultados experimentais obtidos para Co e ligas de $\mathrm{Fe}-\mathrm{Co}$, depositadas a partir da solução de 1:10 ajustaramse ao de um mecanismo de nucleação progressiva. No caso de Fe puro e ligas de $\mathrm{Fe}-\mathrm{Co}$, depositadas a partir das soluções 1:1 e 10:1, o processo de nucleação ocorreu pelo mecanismo de nucleação instantânea. A densidade do número de núcleos calculados variou de 2.6 a $19.1 \times 10^{3} \mathrm{~cm}^{-2}$ para $\mathrm{Fe}$ e a taxa de formação de núcleos para Co de 0.10 a $15.8 \times 10^{6} \mathrm{~cm}^{-2} \mathrm{~s}^{-1}$.
\end{abstract}

The electrodeposition of $\mathrm{Fe}, \mathrm{Co}$ and $\mathrm{Fe}-\mathrm{Co}$ alloys onto $\mathrm{Pt}$ has been investigated from chloride solutions at $\mathrm{pH}$ 2.0. The Fe-Co alloys were deposited from solutions with molar ratio of 1:10, 1:1 and 10:1. Electrocrystallization of metals was studied by potentiostatic steps. The Scharifker and Hills model was used to analyze current transients. A progressive nucleation mechanism was found to fit the experimental results for both $\mathrm{Co}$ and $\mathrm{Fe}-\mathrm{Co}$ alloys deposited from 1:10 solution. In the case of pure $\mathrm{Fe}$ and $\mathrm{Fe}-\mathrm{Co}$ alloy, deposited from 1:1 and 10:1 solutions, the nucleation process occurred by the instantaneous mechanism. The nuclei number densities and rate of nucleation were calculated and their values were 2.6 to $19.1 \times 10^{3} \mathrm{~cm}^{-2}$ for $\mathrm{Fe}$ and 0.10 to $15.8 \times 10^{6} \mathrm{~cm}^{-2} \mathrm{~s}^{-1}$ for Co deposition.

Keywords: nucleation, electrodeposition, iron alloys, electrocrystallization

\section{Introduction}

Electrodeposition is one of the best methods for producing alloys, depositing films with structures different from those obtained by the evaporation method. Many alloys are electrodeposited commercially from plating baths containing a mixture of metal ions in aqueous electrolyte. ${ }^{1-6}$ These alloys are important due to the many possible industrial and technological applications they possess. Electrodeposited thin films of binary alloys of iron group ( $\mathrm{Fe}, \mathrm{Co}$ and $\mathrm{Ni}$ ) are of interest due to the various applications in electronics and microtechnology . The best known example is permalloy, a FeNi alloy used in soft magnetic read/write heads. ${ }^{7,8}$ The cobalt alloys also present interesting magnetic properties making them candidates for disc storage media. ${ }^{7}$ The electrodeposition of irongroup alloys belongs to Brenner's anomalous codeposition category, ${ }^{9}$ which is characterized by the unusual

* e-mail: mascaro@quimica.ufpr.br preferential electrodeposition of less noble metals. The co-deposition of Fe-Co alloys has been less investigated if compared to Fe-Ni alloys. These alloys have been studied in sulfate, ${ }^{10-17}$ citrate $^{18}$ acetate $^{19}$ solutions at different $\mathrm{pHs}$ and morphology, composition and properties of alloys obtained depend on experimental conditions.

Despite of the multiple aspects considered in these studies, the mechanism of the nucleation and electrocrystallization processes of $\mathrm{Fe}, \mathrm{Co}$ and $\mathrm{Fe}-\mathrm{Co}$ alloys in aqueous media have received much less attention. The Co electrodeposition in aqueous solution, for example, is accompanied by simultaneous hydrogen evolution reaction (HER), ${ }^{20,21}$ which makes analysis of experimental current transients of cobalt electrodeposition very difficult. Correia et al..$^{22}$ and Gómez et al. ${ }^{23}$ analyzed the electrocrystallization of Co on carbon and gold substrates, from chloride baths and a progressive nucleation mechanism was found. Soto $e t$ al. ${ }^{24,25}$ studied Co electrodeposition, using different $\mathrm{pHs}$ and concluded that distinct mechanisms of nucleation are involved during early stages of Co deposition. At $\mathrm{pH} 9.4$ 
was observed three different kinds of parallel nucleation processes were observed as well as a $2 \mathrm{D}$ progressive and instantaneous nucleation and 3D progressive nucleation. At $\mathrm{pH} 4.4$ the nucleation process is $3 \mathrm{D}$ progressive. Potential step experiments made by Bertazolli e Sousa ${ }^{26}$ in sulfate solution, $\mathrm{pH}$ 6, showed that Co deposition is formed by a mechanism of progressive nucleation followed by 3-D growth. Bertazolli and Pletcher ${ }^{13}$ also studied Fe-Co alloy nucleation and similar behavior to that of pure Co was found.

Thus, the purpose of the work reported here was to study the electrocrystallization of Fe, Co and Fe-Co alloys onto Pt electrode in chloride medium. Potentiostatic steps were used to investigate the nucleation and growth processes.

\section{Experimental}

The electrochemical measurements were performed with a conventional three-electrode glass cell. The working electrode was built from a $5 \mathrm{~mm}$-diameter platinum disk. The disk was sealed onto a glass tube and the exposed surface $\left(0.202 \mathrm{~cm}^{2}\right)$ was polished to a mirror finishing with a $1 \mu \mathrm{m}$ alumina powder. The auxiliary electrode was a platinum foil with a surface area of $2 \mathrm{~cm}^{2}$. A saturated calomel electrode (SCE) was used as a reference electrode and was connected to the main cell trough a Luggin capillary.

Iron and cobalt were deposited from 0.1 and $0.01 \mathrm{~mol} \mathrm{~L}^{-1} \mathrm{CoCl}_{2}$ and $\mathrm{FeCl}_{2}$ solutions containing $1.0 \mathrm{~mol} \mathrm{~L}^{-1} \mathrm{KCl}$ ( $\mathrm{pH} 2.0$ adjusted by $\mathrm{HCl}$ ). Fe-Co alloys were deposited from $0.1 \mathrm{~mol} \mathrm{~L}^{-1} \mathrm{Fe}$ (II) $+0.1 \mathrm{~mol} \mathrm{~L}^{-1} \mathrm{Co}$ (II) (ratio $1: 1$ ), $0.01 \mathrm{~mol} \mathrm{~L}^{-1} \mathrm{Fe}$ (II) $+0.1 \mathrm{~mol} \mathrm{~L}^{-1} \mathrm{Co}$ (II) (ratio 1:10 ) and $0.1 \mathrm{~mol} \mathrm{~L}^{-1} \mathrm{Fe}$ (II) $+0.01 \mathrm{~mol} \mathrm{~L}^{-1} \mathrm{Co}$ (II) (ratio $10: 1)$ in $1.0 \mathrm{~mol} \mathrm{~L}^{-1} \mathrm{KCl}$ solutions. All the solutions were prepared from analytical grade reagents, using ultrapure Millipore-Q water (Millipore-Q system).

Metal deposition onto platinum was studied by means of the potential step and cyclic voltammetry technique. The cyclic voltammetry were initially carried out between 0.3 and $-1.1 \mathrm{~V}$ at $0.2 \mathrm{~V} \mathrm{~s}^{-1}$, starting from $0.3 \mathrm{~V}$ and negative followed positive scan.

Potentials were controlled with an EG\&G PARC mod. 273A potentiostat/galvanostat linked to a microcomputer PC AT 386 with EG\&G PARC M270 software for experimental control and data acquisition.

\section{Results and Discussions}

\section{Electrodeposition of individual metals ( $\mathrm{Fe}$ and $\mathrm{Co}$ )}

Figure 1 shows typical voltammetric curves obtained for the Pt electrode in a $0.1 \mathrm{~mol} \mathrm{~L}^{-1} \mathrm{FeSO}_{4}$ and $0.1 \mathrm{~mol} \mathrm{~L}^{-1}$
$\mathrm{CoCl}_{2,} 1.0 \mathrm{~mol} \mathrm{~L}^{-1} \mathrm{KCl}$ solution at $\mathrm{pH} 2.0$. The scan potential rate was $20 \mathrm{mVs}^{-1}$. The voltammograms obtained shows the presence of cathodic and anodic peaks associated deposition and dissolution of metals. Fe deposition occurs at more negative potentials than Co deposition because $\mathrm{Co}$ is a nobler metal. The voltammogram obtained for $\mathrm{Fe}$ is similar to the literature in the same solution. ${ }^{27}$

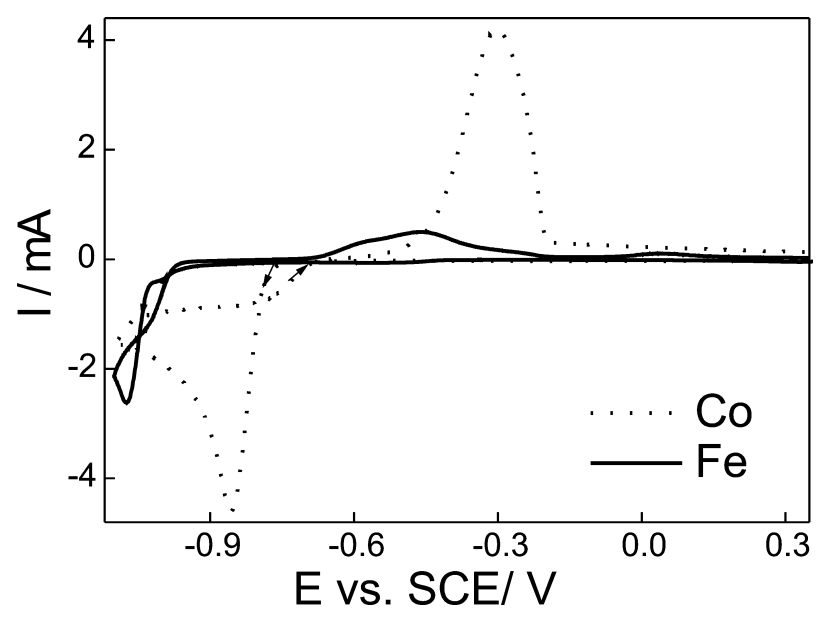

Figure 1. Cyclic voltammograms for $\mathrm{Fe}$ and $\mathrm{Co}$ electrodeposition onto $\mathrm{Pt}$ from $0.1 \mathrm{~mol} \mathrm{~L}^{-1} \mathrm{FeCl}_{2}$ and $0.1 \mathrm{~mol} \mathrm{~L}^{-1} \mathrm{CoCl}_{2}$ in aqueous $1.0 \mathrm{~mol} \mathrm{~L}^{-1}$ $\mathrm{KCl}$ at a scan rate of $20 \mathrm{mV} \mathrm{s}^{-1}$.

Co curve shows one cathodic and one anodic peaks. Bertazolli and Sousa ${ }^{26}$ showed that, at $\mathrm{pH} 2.8$, the stripping peak corresponded to the dissolution of the hydrogen rich phase. Therefore, the peaks in Figure 1 (dashed line) can be associated with the redox couple $\mathrm{Co}\left(\mathrm{H}_{2} \mathrm{O}\right)_{6}{ }^{2+} / \mathrm{Co}(0)$ or $\mathrm{H}^{+} / \mathrm{H}$ reactions. ${ }^{25}$

The voltammograms in Figure 1 show a crossover between cathodic branches current observed for $\mathrm{Fe}$ and Co deposition, which is characteristic of nucleation process. ${ }^{28}$

In order to determine the electrocrystallization and kinetic characteristics of the early stage of phase formation of $\mathrm{Fe}$ and $\mathrm{Co}$ in $1.0 \mathrm{~mol} \mathrm{~L}^{-1} \mathrm{KCl}$ a more convenient potentiostatic method was employed. In this method the nucleation processes were analyzed by selecting an initial potential where no deposition of Fe or Co could be detected in the CVs curves and a final potential less positive located in the region of cathodic peak. Thus potentials jumps were performed from $0.0 \mathrm{~V}$ to more negative potentials. A family of current transients obtained at different potentials is shown in Figure 2. The final potential chosen for Co deposition was between -0.86 and $-0.90 \mathrm{~V}$ where nothing hydrogen ion reduction was expected. For Fe deposition the potential range was between -1.0 and $-1.08 \mathrm{~V}$. 

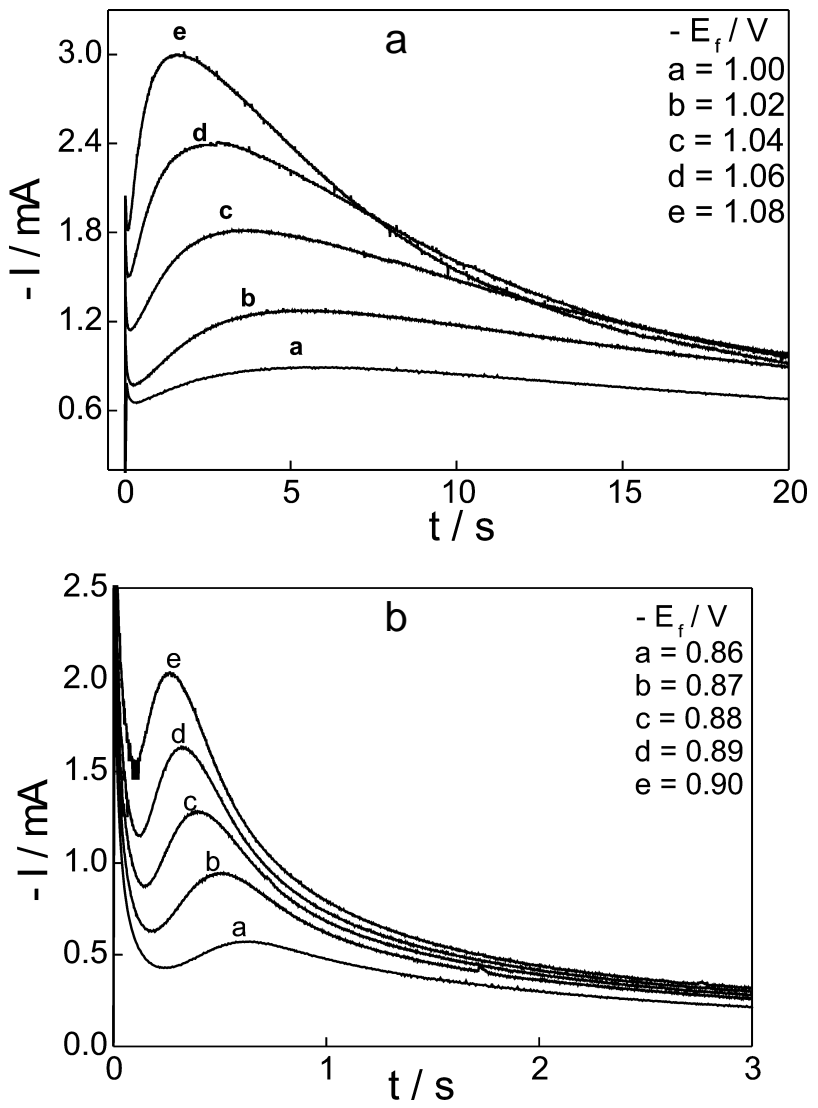

Figure 2. Current transients for $\mathrm{Fe}(\mathrm{a})$ and $\mathrm{Co}$ (b) deposition from $0.01 \mathrm{~mol} \mathrm{~L}^{-1} \mathrm{FeCl}_{2}$ and $0.01 \mathrm{~mol} \mathrm{~L}^{-1} \mathrm{CoCl}_{2}$ in aqueous $1.0 \mathrm{~mol} \mathrm{~L}^{-1} \mathrm{KCl}$ Initial potential $0.0 \mathrm{~V}$ and final potentials are indicated in the figure.

It can be seen in Figure 2, that current increases rapidly to a maximum ( $\mathrm{I}_{\max }$ and $\mathrm{t}_{\max }$ ) and then decreases gradually with time. Moreover $\mathrm{I}_{\max }$, increases and $\mathrm{t}_{\max }$ decrease with E. The initial decreasing current corresponding to the charging of the double layer followed by the rising current, is due either to the growth of a new phase and/or to an increase of the number nuclei. During this stage of deposit growth, the nuclei develop diffusion zones around themselves. As these zones overlap the hemispherical masstransfer give way to a linear mass-transfer resulting in an effectively planar surface. The current then falls that corresponding to linear diffusion. This is the limiting diffusion current for the deposition process. These curves show a typical response of a three-dimensional (3D) multiple nucleation with diffusion controlled growth. ${ }^{29}$ Kinetic information about electrocrystallization process could then be obtained by analyzing the rising portion and the maximum of the experimental current transients.

\section{Analysis of the rising portion of the current transients}

In this case no overlapping of growing nuclei is considered, i.e., only isolated nuclei are present on the surface. Scharifker and Hills ${ }^{29}$ considered two types of nucleations, and proposed the following current-time relationships:

$i=z F D^{3 / 2} C^{1 / 2} N k t^{1 / 2}$

for instantaneous nucleation in which the nuclei are formed at beginning of the pulse; and

$i=z F D^{3 / 2} C^{1 / 2} A N_{\infty} k^{1} t^{3 / 2}$

for progressive nucleation in which the nuclei are continuously formed during the crystal growth.

In equations (1) and (2), $k=\left(\frac{8 \pi C M}{\rho}\right)^{1 / 2}, k^{\prime}=\frac{4}{3}\left(\frac{8 \pi C M}{\rho}\right)^{1 / 2}$, $i$ is current density, $\mathrm{t}$ is time, $\mathrm{D}$ is the diffusion coefficient, $\mathrm{C}$ is the bulk concentration, $\mathrm{zF}$ is the molar charge transferred during electrodeposition, $\mathrm{M}$ and $\rho$ are molecular weight and density of the materials, respectively, $\mathrm{N}$ is the total number nuclei, $\mathrm{A}$ is the steady state nucleation rate constant per site and $\mathrm{N}_{\infty}$ the number density of active sites.

Under this approach, in order to evaluate the kinetics parameters of the electrodeposition process, it becomes necessary to classify the nucleation process as either instantaneous or progressive. Analysis of the early stages of deposition is possible by representing, to initial transient portion, I $v s . \mathrm{t}^{1 / 2}$ for instantaneous (equation 3 ) and I $v$ s. $\mathrm{t}^{3 / 2}$ for progressive nucleation (equation 4). For the experiments data, showed in Figure 2a, plots of $\mathrm{I} v$ s. $\mathrm{t}^{1 / 2}$ and $\mathrm{I} v \mathrm{~s} . \mathrm{t}^{3 / 2}$ are presented in Figure 3 where it is possible to observe that a better linearity is obtained for I $v s . \mathrm{t}^{1 / 2}$ plot. These results indicate that, under the experimental conditions analyzed here, an instantaneous Fe nucleation process occurs. In the case of Co deposition, however, the type of nucleation was not possible to establish, by this approach, since the current corresponding of the rising part of the curves in Figure $2 \mathrm{~b}$ were found to be linear $v s$. both $\mathrm{t}^{1 / 2}$ and $\mathrm{t}^{3 / 2}$. Soto et al. ${ }^{25}$ observed the same behavior for Co deposition onto glassy carbon electrode. A more detailed quantitative analysis, based in the current maximum data, can be made for over current transients range.

\section{Analysis of the current maximum}

For the 3D multiple nucleation with diffusion controlled growth expressions normalized in terms of the current maximum, $\mathrm{I}_{\max }$, and the time which the current maximum observed, $t_{\text {max }}$ have been obtained for instantaneous nucleation:

$\left(\frac{\mathrm{I}}{\mathrm{I}_{\text {max }}}\right)^{2}=\frac{1.9542}{\mathrm{t} / \mathrm{t}_{\max }}\left\{1-\exp \left[-1.2564\left(\frac{\mathrm{t}}{\mathrm{t}_{\text {max }}}\right)\right]\right\}^{2}$ 

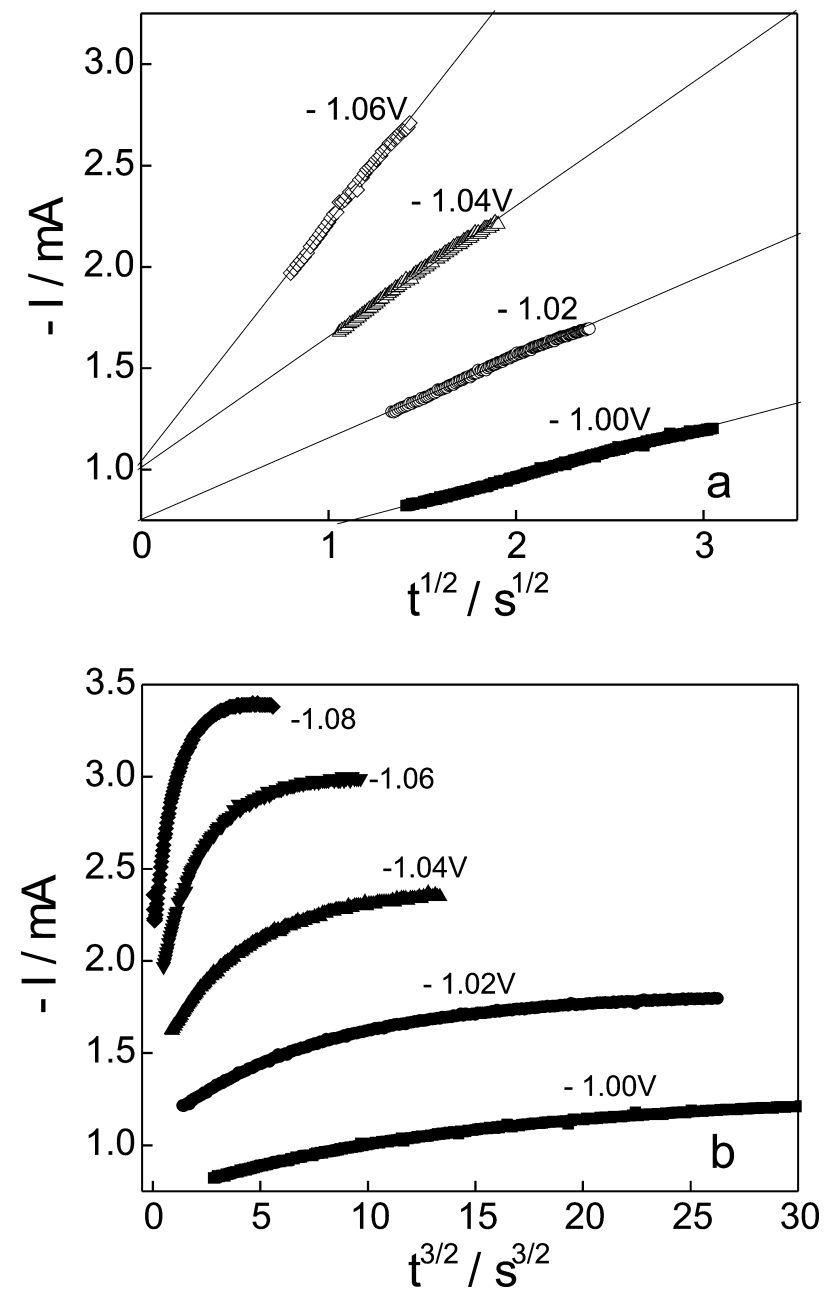

Figure 3. Dependence between I vs. $\mathrm{t}^{1 / 2}$ (a) and I $v s$. $\mathrm{t}^{3 / 2}$ (b) plots for initial transient portion from Figure 2a for $\mathrm{Fe}$ deposition onto Pt.

and progressive nucleation

$$
\left(\frac{\mathrm{I}}{\mathrm{I}_{\text {max }}}\right)^{2}=\frac{1.2254}{\mathrm{t} / \mathrm{t}_{\text {max }}}\left\{1-\exp \left[-2.3367\left(\frac{\mathrm{t}}{\mathrm{t}_{\text {max }}}\right)^{2}\right]\right\}^{2}
$$

These expressions describe both the rising and falling portions of the transients. ${ }^{13,14}$

A convenient criterion, for distinguishing between these two cases of nucleation kinetics, is to present the experimental data in a non-dimensional plot $\left(\mathrm{I} / \mathrm{I}_{\max }\right)^{2} v s$. $\mathrm{t} / \mathrm{t}_{\max }$ and to compare these with theoretical plots resulting from equations (3) and (4). This method of obtaining kinetic information of the nucleation process has been used extensively for a wide variety of systems. ${ }^{22-26,30-34}$

Some of the non-dimensional plots obtained with the experimental and theoretical data are shown in Figure 4. It is clear from this figure that $\mathrm{Fe}$ deposition on Pt follows very close the theoretical response for an instantaneous nucleation, over the measured potential range. This result is in accordance with those obtained through analysis of Figure 2. Cobalt deposition data are better described by theoretical non-dimensional plots for progressive nucleation, although in $\mathrm{t} / \mathrm{t}_{\max }<0.4$ an anomalous behavior is observed. According to Soto et al. ${ }^{25}$ this is possible due to the presence of the other phenomena not considered in our approach e.g. adsorption process ${ }^{35}$ or monolayer formation $^{36}$ or the magnitude of the charging current. This current is much higher for $\mathrm{Co}$ than $\mathrm{Fe}$ and could be crucial in the early stages of nuclei formation.
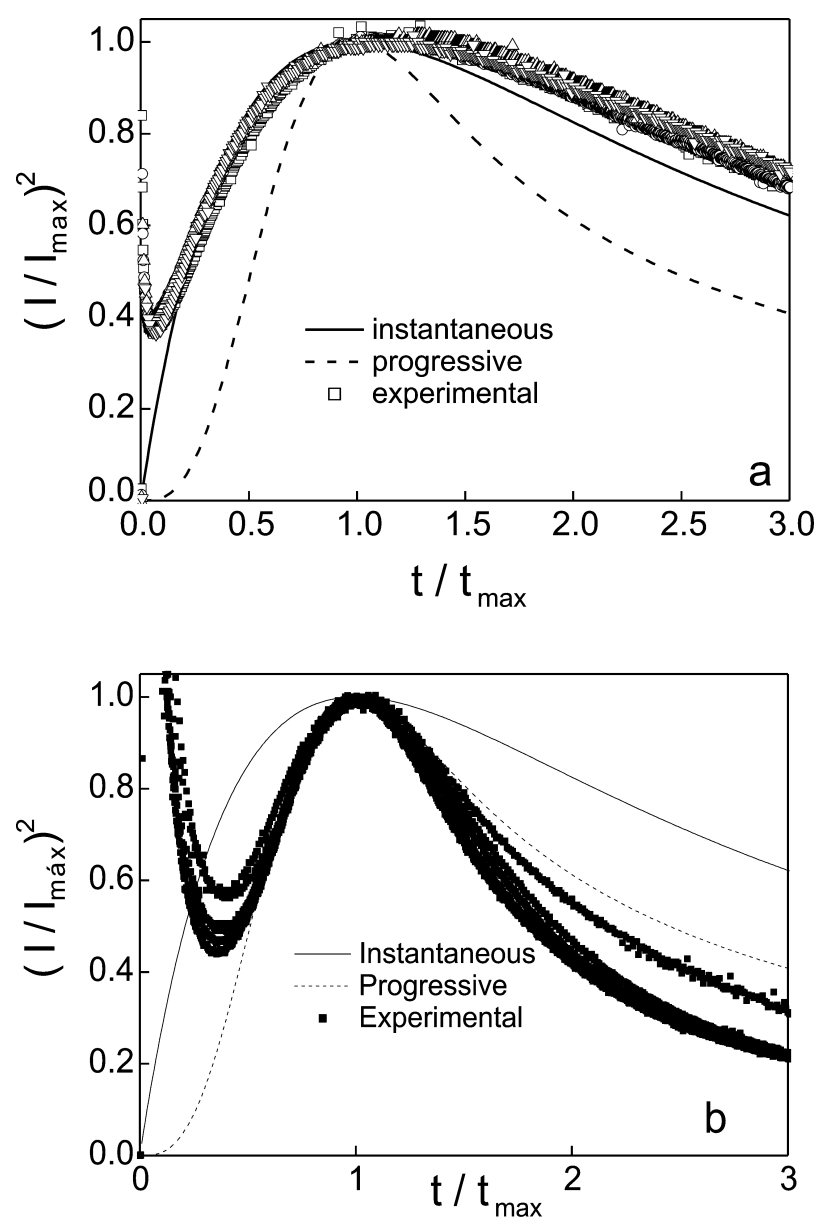

Figure 4. Non-dimensional plots, $\mathrm{I}^{2} / \mathrm{I}^{2}{ }_{\max } v s . \mathrm{t} / \mathrm{t}_{\max }$, according to the set equations (5) and (6) for (-) instantaneous and (- - -) progressive nucleation limiting cases. Points represent experimental curves from Figure 2 for $\mathrm{Fe}$ (a) and $\mathrm{Co}$ (b) deposition onto Pt.

In Figure 4 can be observed that theoretical curve described adequately almost the whole current transients, therefore is possible to classify, the systems studied in this paper, as 3D multiple nucleation with diffusion controlled growth. From Figure 4a it is evident that nucleation of Fe on Pt follows closely the response predicted for instantaneous nucleation and Co follows the response 
predicted for progressive nucleation. The present results are accordance with the literature where Co electrocrystallization, studied under different experimental conditions, occurred by a progressive nucleation process. ${ }^{22-26}$ The quantitative analysis of Fe nucleation nothing has been found in the literature.

Another resulting expressions for 3D multiple nucleation model can be represented by the product $\mathrm{i}^{2}{ }_{\max } \mathrm{t}_{\max }$, which dos not contain the quantities $\mathrm{k}, \mathrm{k}, \mathrm{AN}_{\infty}$ or $\mathrm{N}$ and is therefore a convenient diagnostic criterion of the particular form nucleation occurring. The expressions for $\mathrm{i}^{2} \mathrm{t}_{\max }$ are represented in equations (5) and (6).

$$
\begin{aligned}
& \text { instantaneous } \quad i_{\text {max }}{ }^{2} t_{\text {max }}=0.1629(n F C)^{2} \\
& \text { progressive } \quad i_{\text {max }}{ }^{2} t_{\text {max }}=0.2598(n F C)^{2} D
\end{aligned}
$$

The treatment of the potentiostatic transient based in equations (5) and (6), discussed above, requires the product $\mathrm{i}_{\text {max }}^{2} \mathrm{t}_{\max }$, to be independent of the nucleation and growth rate. Thus, at a given bulk concentration of electrodepositing species $\mathrm{i}^{2}{ }_{\text {max }} \mathrm{t}_{\max }$ should not vary with the overpotential for sufficiently high steps potentials, for which the surface concentration of metal ions is effectively zero. That this so is in Table 1, where the values of that product $\left(\mathrm{i}_{\max }^{2} \mathrm{t}{ }_{\max }\right)$ remain practically constant, within experimental error, for more negative potentials, as required by $3 \mathrm{D}$ multiple nucleation model. For more positive potentials, the product $\mathrm{i}_{\text {max }}^{2} \mathrm{t}_{\max }$ changes, because the surface concentration of metals ions no is effectively zero.

Once it is established that the nucleation type, it is possible calculate total number nuclei $(\mathrm{N})$ or number density of active sites $\left(\mathrm{AN}_{\infty}\right)$ at different potentials can be calculated from the current maximal by means equations (7) and (8). The values thus obtained also appear in Table 1.

Instantaneous $i_{\max }=0.6382 z F D C(k N)^{1 / 2}$

Progressive $i_{\max }=0.4615 z F D^{3 / 4} c\left(k^{\prime} A N_{\infty}\right)^{1 / 4}$

The diffusion coefficients (D) employed was determined from mean value of the quantify $\mathrm{i}^{2}{ }_{\max } \mathrm{t}_{\max }$ which were $5.7 \times 10^{-6} \mathrm{~cm}^{2} \mathrm{~s}^{-1}$ for Fe and $2.3 \times 10^{-5} \mathrm{~cm}^{2} \mathrm{~s}^{-1}$ for Co. These values are close to those obtained from an I vs. $\mathrm{t}^{-1 / 2}$ plot decaying portion of high overpotential transients by means of the Cottrell equation, i.e. $\mathrm{D}=4.9 \times 10^{-6} \mathrm{~cm}^{2} \mathrm{~s}^{-1}$ for Fe and D $=2.7 \times 10^{-5} \mathrm{~cm}^{2} \mathrm{~s}^{-1}$ for Co. This values also are according values present in literature which are of $1.8 \mathrm{x}$ $10^{-5} \mathrm{~cm}^{2} \mathrm{~s}^{-1}$ for $\mathrm{Co}(\mathrm{II})^{25}$ and $3.0 \times 10^{-6} \mathrm{~cm}^{2} \mathrm{~s}^{-1}$ for Fe. ${ }^{37}$

The values of $\mathrm{N}$ and $\mathrm{AN}_{\infty}$ listed in Table 1, were used to plot the dependence of $\ln \mathrm{N}$ or $\ln \mathrm{AN}_{\infty} v s . \mathrm{E}$ (Figure 5). This
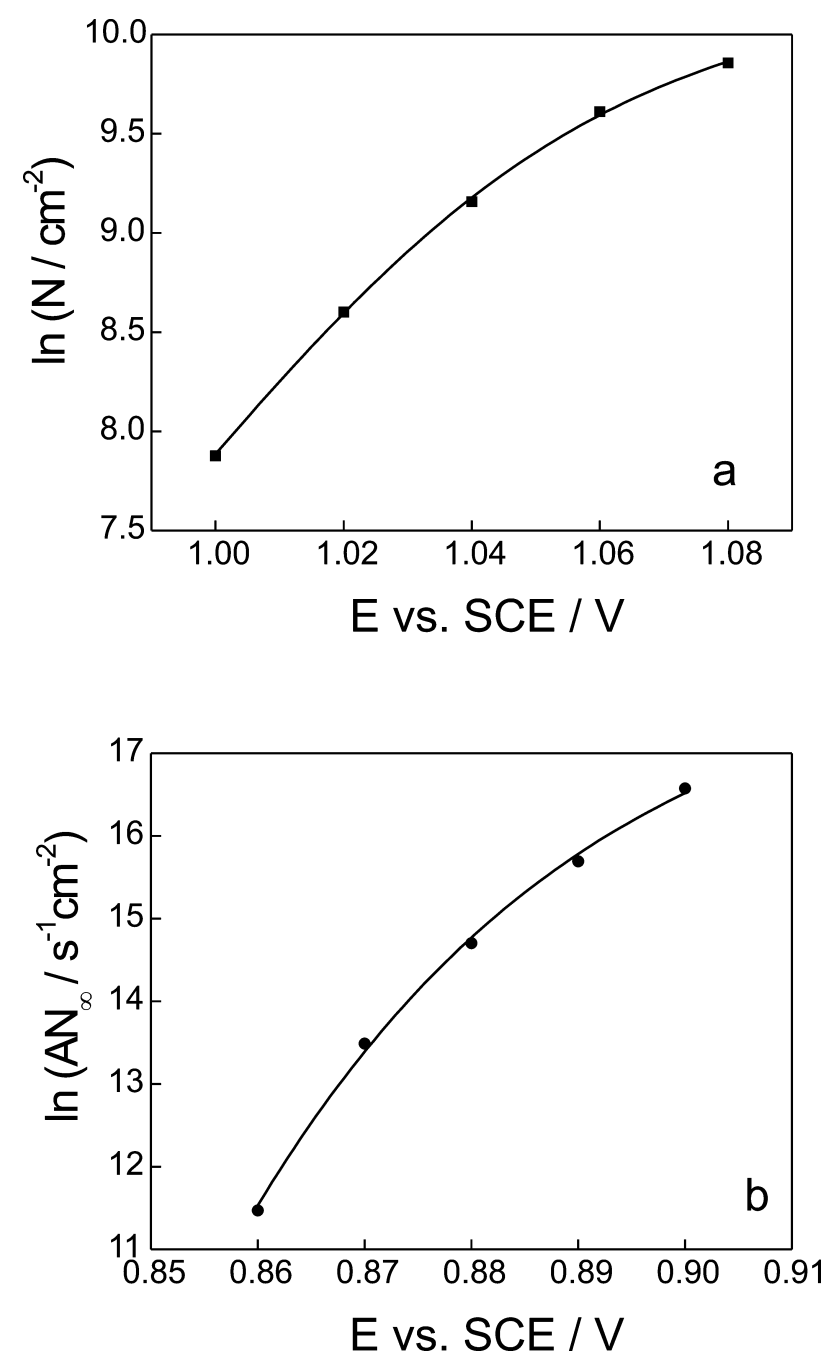

Figure 5. Plot of $\log \mathrm{N}$ vs. $\mathrm{E}$ for $\mathrm{Fe}$ (a) and $\log \mathrm{AN}_{\infty}$ for $\mathrm{Co}$ (b) deposition onto Pt.

\begin{tabular}{|c|c|c|c|c|c|}
\hline \multicolumn{3}{|c|}{$\mathrm{Fe}$} & \multicolumn{3}{|c|}{ Co } \\
\hline$-\mathrm{E}_{\mathrm{f}} / \mathrm{V}$ & $10^{4} \mathrm{i}_{\max }^{2} \mathrm{t}_{\max } / \mathrm{A}^{2} \mathrm{~cm}^{-4} \mathrm{~s}^{-1}$ & $10^{-3} \mathrm{~N} / \mathrm{cm}^{-2}$ & $-\mathrm{E}_{\mathrm{f}} / \mathrm{V}$ & $10^{5} \mathrm{i}_{\text {max }}^{2} \mathrm{t}_{\max } / \mathrm{A}^{2} \mathrm{~cm}^{-4} \mathrm{~s}^{-1}$ & $10^{-6} \mathrm{AN}_{\infty} / \mathrm{s}^{-1} \mathrm{~cm}^{-2}$ \\
\hline 1.00 & 1.25 & 2.6 & 0.86 & 0.54 & 0.1 \\
\hline 1.02 & 2.18 & 5.4 & 0.87 & 1.15 & 0.7 \\
\hline 1.04 & 3.47 & 9.5 & 0.88 & 1.79 & 2.4 \\
\hline 1.06 & 3.42 & 14.9 & 0.89 & 2.23 & 6.5 \\
\hline 1.08 & 3.46 & 19.1 & 0.90 & 2.24 & 15.8 \\
\hline
\end{tabular}

Table 1. Analysis of the current maxima for deposition of $\mathrm{Fe}$ and Co onto Pt electrode 
figure shows that an increased $\mathrm{E}$ leads to a higher $\mathrm{N}$ and $\mathrm{AN}_{\infty}$, but with a diminishing gradient and when $\mathrm{E}$ is high enough, $\mathrm{N}$ and $\mathrm{AN}_{\infty}$ will eventually saturate. The gradient is higher to Co than to $\mathrm{Fe}$.

\section{Electrodeposition of $\mathrm{Fe}$-Co alloys}

In the case of $\mathrm{Fe}-\mathrm{Co}$ deposition with solutions with various concentrations of $\mathrm{Fe}$ and $\mathrm{Co}$ were studied. The ratio molar Fe:Co used were 1:1, 1:10 and 10:1. The voltammetric curves obtained for each molar ratio are shown in Figure 6. The voltammograms have the same general form and the potential stripping peak changes when molar ratio of metals ions is modified. The potential and number stripping peaks in the voltammograms of Fe-Co deposition depend upon the scan potential reverse and is associate at different phase and/or alloys composition. ${ }^{27,38-40}$

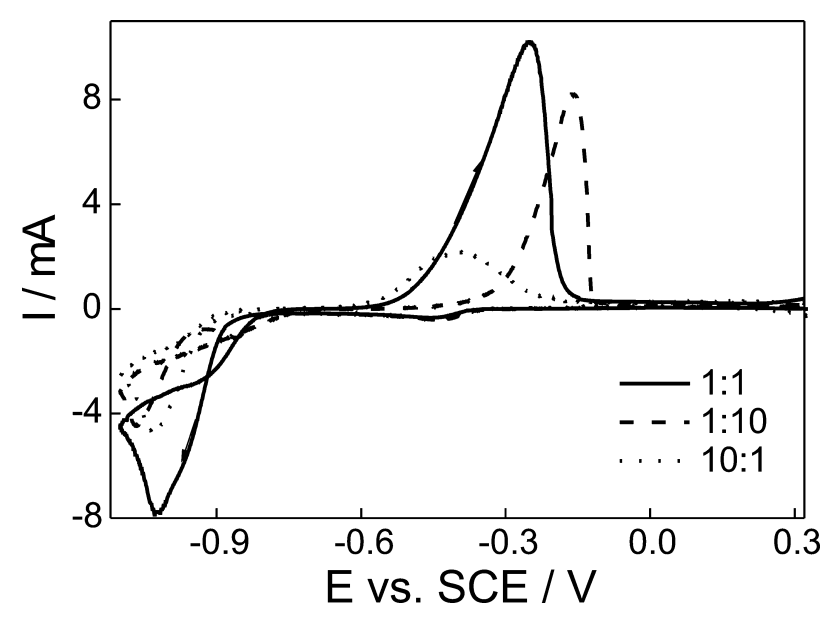

Figure 6. Cyclic voltammograms for Fe-Co alloys deposition from ratio molar concentrations 10:1, 1:1 and 1:10 on Pt from in $1.0 \mathrm{~mol} \mathrm{~L}^{-1}$ $\mathrm{KCl}$ at a scan rate of $20 \mathrm{mV} \mathrm{s}^{-1}$.

Several experiments were carried out with each of the solutions $(1: 1,1: 10$ and 10:1) and the results are shown in Figure 7. The current transients presented similar behavior to those of individual metals, however with lower definition in maximal current and with higher interference of the charging current. This aspect of transients indicates that it will be difficult to performed the same analysis for individuals metals curves, specially the rising portion of the transients. Thus we will only presented nondimensional plots for Fe-Co deposition.

The Figure 8 shows non-dimensional plots data for $\mathrm{Fe}-$ Co deposition at ratio molar of 1:10, 1:1 and 10:1 in the potential step of $-1.18,-1.12$ and $-0.92 \mathrm{~V}$, respectively. As expected, a large decaying current observed at beginning of each transient, due to doubly layer charging, obscure
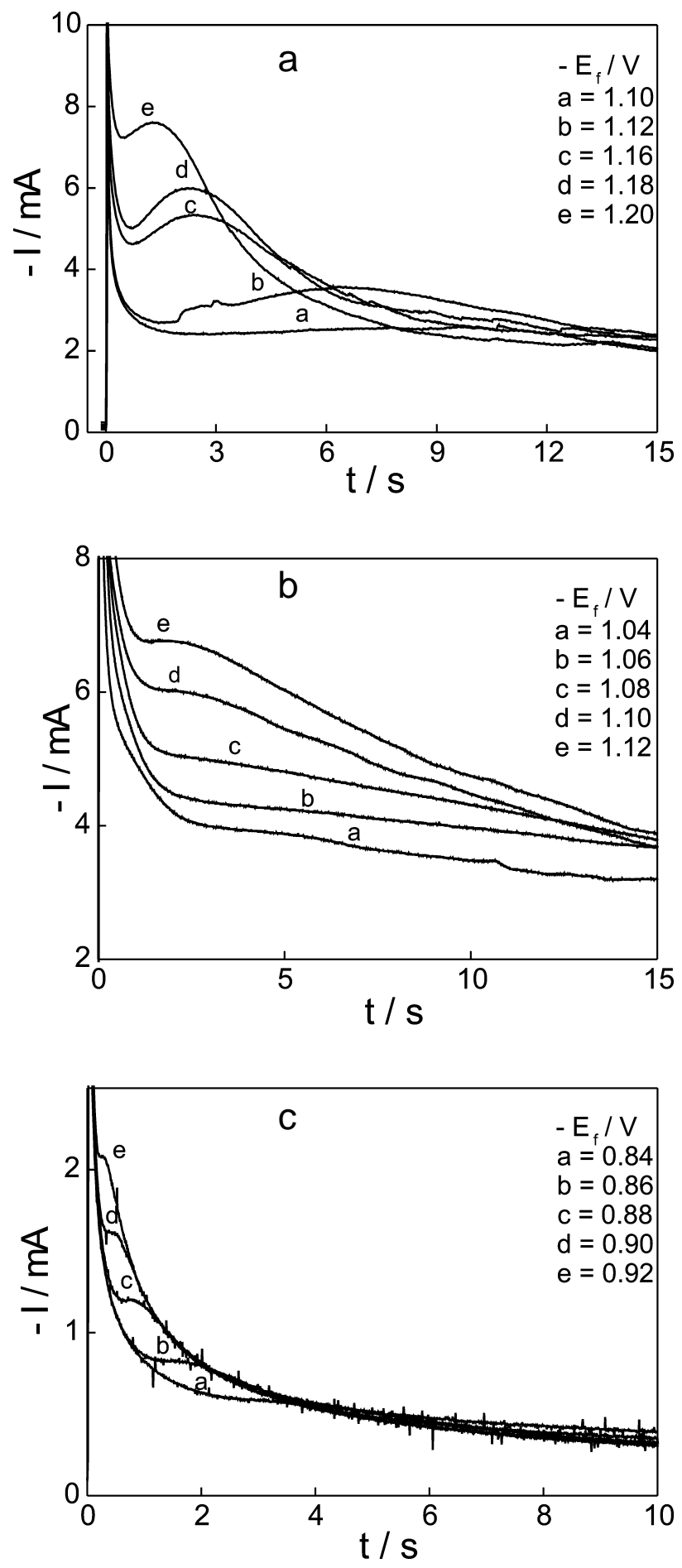

Figure 7. Current transients for Fe-Co alloys deposition from ratio molar concentrations 10:1 (a), 1:1 (b) and 1:10 (c). Initial potential $0.0 \mathrm{~V}$; final potentials are indicated in figure.

the nuclear growth current at short times. Thus the theoretical curve no described adequately whole current transient. For 1:1 and 10:1 ratio, the fit between experimental and theoretical instantaneous curves, occurs near the current maximal up to end curves, what may be 
indicative that for these alloys the mechanism of nucleation is instantaneous. For 1:10 ratio as charging current is even higher the fit between theoretical and experimental curves occurs only depart of the current maximal up end curve. Consequently the analysis for this case is more difficult but we can to say that the results indicated that progressive nucleation occurs for $\mathrm{Fe}: \mathrm{Co}$ deposition in 1:10 ratio.

Therefore, if we consider that above conclusions are correct, we can be concluded that solutions with $\mathrm{Fe}$ concentration equal or higher than that of Co have similar behavior as pure $\mathrm{Fe}$. When Co concentration is higher than $\mathrm{Fe}$ the nucleation process resemble to that of pure Co. Bertazzoli and Pletcher ${ }^{13}$ observed that Fe-Co alloys layers are formed by mechanisms involving progressive nucleation followed by three dimensional growth at $\mathrm{pH}$ 4.0 in sulphate electrolyte. No data were found respect $\mathrm{Fe}$ Co deposition at chloride medium.

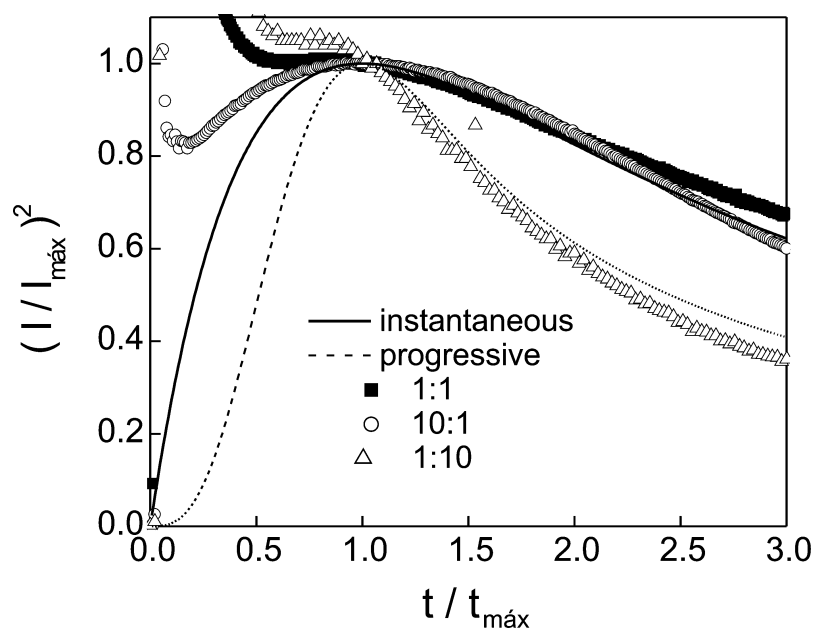

Figure 8. Non-dimensional plots, $\mathrm{I}^{2} / \mathrm{I}^{2}{ }_{\max } v s . \mathrm{t} / \mathrm{t}_{\max }$, according to the set equations (5) and (6) for (-) instantaneous and (- - ) progressive nucleation limiting cases. Points represent experimental curves from Figure 7 for of $\mathrm{Fe}$-Co alloys deposition.

\section{Conclusions}

Considering the results reported here, it can be concluded that electrodeposition of both, $\mathrm{Fe}$ and $\mathrm{Co}$, onto Pt electrode from chloride solution ( $\mathrm{pH} 2.0)$ occurs via 3D multiple nucleation with diffusion controlled growth, following the Scharifker and Hills model. Fe deposition fitted an instantaneous nucleation mechanism and $\mathrm{Co}$ shown a progressive process.

Analysis detailed of the maximum of experimental current transients allows us to determine the number nuclei density for $\mathrm{Fe}$ and rate of nucleation $\left(\mathrm{AN}_{\infty}\right)$ for $\mathrm{Co}$.
Fe-Co alloys deposition exhibited an instantaneous nucleation mechanism for ions ratio molar of 1:1 and 10:1, as that pure Fe deposition. When Co content was increased (Fe-Co 1:10) the nucleation mechanism followed progressive model.

\section{Acknowledgements}

The authors wish to thank to the Conselho Nacional de Pesquisa e Desenvolvimento (CNPq) and Fundação Araucária for financial support.

\section{References}

1. Miyake, T.; Kume, M.; Yamaguchi, K.; Amalnerkar, D. P.; Minoura, H.; Thin Solid Films 2001, 397, 83.

2. Zaky, A. M.; Pickering, H. W.; Weil, K. G.; Plat. Surf. Finish. 2001, 10, 48.

3. Coey, J. M. D.; Hinds, G.; J. Alloys Compd. 2001, 326, 238.

4. Hasegawa, R.; Physica B 2001, 299, 199.

5. Toth-Kadar, E.; Peter, L.; Becsei, T.; Toth, J.; Pogany, L.; Tarnoczi, T.; Kamasa, P.; Bakonyi, I.; Lang, G.; Cziraki, A.; Schwarzacher, W.; J. Electrochem. Soc. 2000, 147, 3311.

6. Schwarzacher, W.; Lashmore, D. S.; IEEE Trans. Magn. 1996, 32, 3133.

7. Andricacos, P. C.; Romankiv, T. ; Advances in Electrochemical Science and Engineering; Editora John Willey: New York 1994, p. 226.

8. Ohashi, K.; Ito, M.; Watanabe, M.; Electrochem. Soc. Proc. 1988, 88, 525 .

9. Brenner, A.; Electrodeposition of Alloys, Academic Press: New York, 1963, Vols 1-2.

10. Ebothe, J.; Vilain, S.; J. Phys. D: Appl. Phys. 1999, 32, 2342.

11. Zech, N.; Podlaha, E. J.; Landolt, D.; J. Appl. Electrochem. 1998, 28, 1251.

12. Kakuno, E. M.; Mosca, D. H.; Mazzaro, I.; Mattoso, N.; Schreiner, W. H.; Gomes, M. A. B.; Cantão, M. P.; J. Electrochem. Soc. 1997, 144, 3222.

13. Bertazzoli, R.; Pletcher, D.; Electrochim. Acta 1993, 38, 671.

14. Sasaki, K. Y.; Talbot, J. B.; J. Electrochem. Soc. 1998, 145, 981.

15. Sasaki, K. Y.; Talbot, J. B.; J. Electrochem. Soc. 1995, 142 , 775.

16. Vilain, S.; Ebothe, J.; Mater. Sci. Eng., C 2001, 15, 199.

17. Ricq, L.; Lallemand, F.; Gigandet, M. P.; Pagetti, J.; Surf. Coat. Technol. 2001, 138, 278.

18. Berezina, S. I.; Sharapova, L. G.; Shtyrlin, V. G.; Khodyrev, Y. P.; Prot. Met. 1994, 30, 154.

19. Abd, E. L.; Rehim, S. S.; Khaled, K.; Abulkibash, A. M. S.; Emad, M.; Trans. Inst. Met. Finish. 2000, 78, 41.

20. Cui, C. Q.; Jiang, S. P.; Tseung, A. C. C.; J. Electrochem. Soc. 1991, 138, 1001 . 
21. Croll, I. M.; May, B. A. In Electrodeposition Technology, Theory and Practice; Romankiw, L.T.;. Turner, D.R., eds., The Electrochem. Soc. Softbound Proceedings Series: Pennington, 1987, p. 295.

22. Correia, A. N.; Machado, S. A. S.; Avaca, L. A.; J. Electroanal. Chem. 2000, 488, 110.

23. Goméz, E.; Marin, M.; Sanz, F.; Valles, E.; J. Electroanal. Chem. 1997, 422, 139.

24. Palomar-Pardave, M.; Gonzalez, I.; Soto, A. B.; Arce, E. M.; J. Electroanal. Chem. 1998, 443, 125.

25. Soto, A. B.; Arce, E. M.; Palomar-Pardave, M.; Gonzalez, I.; Electrochim. Acta 1996, 41, 2647.

26. Bertazzoli, R.; Sousa, A. D. F. B.; J. Braz. Chem. Soc. 1997, 8 , 357.

27. Goméz, E.; Pelaez, E.; Vallés, E.; J. Electroanal. Chem. 1999, 469, 139.

28. Fletcher, S.; Electrochim. Acta 1983, 28, 917.

29. Scharifker, B.; Hills, G.; Electrochim. Acta 1983, $28,879$.

30. Ortega, J. M.; Thin Solid Films 2000, 360, 159.

31. Milchev, A.; Stoychev, D.; Lazarov, V.; Papoutsis, A.; Kokkinidis, G.; J. Cryst. Growth 2001, 226, 138.
32. Milchev, A.; Michailova, E.; Electrochem. Commun. 2000, 2 , 15.

33. Arbib, M.; Zhang, B.; Lazarov, V.; Stoychev, D.; Milchev, A.; Buess-Herman, C.; J. Electroanal. Chem. 2001, 510, 67.

34. Correia, A. N.; Machado, S. A. S.; J. Braz. Chem. Soc. 1997, 8,71 .

35. Bosco, E.; Rangarajan, S. K.; J. Electroanal. Chem. 1982, 134, 213.

36. Hills, G. J.; Schiffrin, D. J.; Thompson, J.; Electrochim. Acta. 1974, 19, 657.

37. Azambuja, D. S.; Muller, I. L.; Feris, L. A.; Ladeira, F.; Ries, L. S.; Corros. Sci. 1996, 38, 1235.

38. Kirilova, I.; Ivanov, I.; Rashkov, S.; J. Appl. Electrochem. 1998, 28, 1359.

39. Jovic, V. D.; Jevtic, V.; Electrochim. Acta 1998, 43, 63.

40. Swathirajan S.; J. Electroanal. Chem. 1987, 221, 211.

Received: January 17, 2002

Published on the web: July 26, 2002 